prednisolone. Procedures were performed by 2 physicians or by 1 physician and a nurse, using conscious sedation with alfentanyl and midazolam. One patient required deeper sedation [remifentanyl and propofol] due to a complicated medical history. Bronchial thermoplasty was administered in three sessions, treating the right lower lobe, the left lower lobe and both upper lobes respectively. Follow up is at 3 monthly intervals for both safety and efficacy outcomes.

Results Between $2^{\text {nd }}$ June 2011 and $30^{\text {th }}$ April 2012, ten patients underwent bronchial thermoplasty in Glasgow [7 males, 3 females] (Table 1). Six patients were at Step 5 and four at Step 4 of the British Guideline on the Management of Asthma scale. 4/10 were taking oral prednisolone daily and $2 / 10$ were receiving omalizumab treatment [for $4^{\text {th }}$ year and $3^{\text {rd }}$ year respectively]. Treatment sessions were largely uneventful and adverse effects were similar to those reported in clinical trials. To date, there has been a reduction in some asthma medications: two patients receiving omalizumab have successfully discontinued treatment; those taking oral steroids are being weaned off prednisolone.

Conclusion Bronchial thermoplasty can be safely delivered in a clinical setting to patients with severe asthma.

References

1. Thomson NC, Bicknell S, Chaudhuri R Bronchial thermoplasty for severe asthma. Curr Opin Allergy Clin Immunol 2012; 12:241-248.

Abstract P5 Table 1 Baseline demography of 10 patients with severe asthma treated with bronchial thermoplasty

\begin{tabular}{|c|c|c|}
\hline & Mean [SD] & Min-Max \\
\hline Age (years) & $48[10]$ & $35-65$ \\
\hline Beclometasone equivalent ICS dose $(\mu \mathrm{g})$ & 2580 [1425] & $1000-6000$ \\
\hline ACT Score & $11.3[4.27]$ & $6-20$ \\
\hline AOLO Score & $3.94[0.83]$ & $2.7-5.1$ \\
\hline HADS Total & $11.6[8.7]$ & $2-27$ \\
\hline $\mathrm{FEV}_{1},(\mathrm{~L})$ & $2.55[0.6]$ & $1.6-3.46$ \\
\hline $\mathrm{FEV}_{1}(\%$ predicted $)$ & $71.4[16.8]$ & $43-96$ \\
\hline Exhaled nitric oxide (ppb) & $43[40]$ & $2.7-126$ \\
\hline Exacerbations in past 12 months & $2.9[3.1]$ & $0-8$ \\
\hline Hospital admissions/A\&E in past 12 months & $1[1.9]$ & $0-5$ \\
\hline
\end{tabular}

Abbreviations $A C T=$ asthma control test; $A O L O=$ asthma quality of life questionnaire; $\mathrm{HADS}=$ hospital anxiety and depression scale, $\mathrm{FEV}_{1}=$ forced expired volume in one second.

\section{P6 FLUTICASONE PROPIONATE/FORMOTEROL FUMARATE COMBINATION THERAPY HAS AN EFFICACY PROFILE SIMILAR TO THAT OF ITS INDIVIDUAL COMPONENTS ADMINISTERED CONCURRENTLY}

doi:10.1136/thoraxjnl-2012-202678.147

T Mclver, B Grothe, M Jain, S Dissanayake. Mundipharma Research Limited, Cambridge, United Kingdom

Background A new asthma therapy containing a combination of the inhaled steroid fluticasone propionate (FLUT) and the longacting $\beta_{2}$ agonist (LABA) formoterol fumarate (FORM) in a metereddose inhaler has been developed (FLUT/FORM; flutiform $\left.{ }^{\circledR}\right)$. In a double-blind, double-dummy, randomised, multicentre, four arm parallel group study, the efficacy and safety of FLUT/FORM vs. FLUT and FORM administered concurrently (FLUT+FORM) was assessed. Here we present efficacy results of a post-hoc subgroup analysis comparing FLUT/FORM 500/20 $\mu \mathrm{g}$ vs. FLUT+FORM 500 $\mu \mathrm{g}+24 \mu \mathrm{g}$ (both twice-daily) by baseline asthma severity.

Methods In total, 620 patients were randomised 1:1:1:1 to receive FLUT/FORM 500/20 $\mu \mathrm{g}$, FLUT/FORM 100/10 $\mu \mathrm{g}$, FLUT+FORM
$500 \mu \mathrm{g}+24 \mu \mathrm{g}$ or FLUT $500 \mu \mathrm{g}$. Randomisation was stratified by percentage predicted $\mathrm{FEV}_{1}$ at baseline [ $\geq 40-\leq 60 \%$ ('severe asthma'; $52 \%$ of patients) vs. $>60 \%-\leq 80 \%$ ('moderate asthma'; $48 \%$ of patients)], allowing a post-hoc dichotomised analysis by baseline $\mathrm{FEV}_{1}$ severity of spirometric and symptom-based endpoints.

Results Similar improvements in lung function (change in predose $\mathrm{FEV}_{1}$ and change in 2-hour post-dose $\mathrm{FEV}_{1}$ ) were seen in the FLUT/FORM 500/20 $\mu \mathrm{g}$ treatment group and the FLUT+FORM $500 \mu \mathrm{g}+24 \mu \mathrm{g}$ treatment group overall [treatment difference 0.079 (95\% CI: $-0.032,0.190) P=0.164$ and treatment difference 0.040 (95\% CI $-0.069,0.149) P=0.471$, respectively]. Both severe and moderate asthmatic subgroups demonstrated mean changes from baseline approximating or exceeding a minimally important improvement $(200 \mathrm{~mL})^{1}$ with similar efficacy in the FLUT/FORM $500 / 20 \mu \mathrm{g}$ and the FLUT+FORM $500 \mu \mathrm{g}+24 \mu \mathrm{g}$ moderate and severe subgroups (Table 1 ).

There were no statistically significant or clinically relevant differences overall or in either of the subgroups between FLUT/FORM $500 / 20 \mu \mathrm{g}$ and FLUT+FORM $500 \mu \mathrm{g}+24 \mu \mathrm{g}$ for any symptombased endpoints. These included asthma symptom scores, sleep disturbance scores, rescue medication use and asthma control days.

Conclusion FLUT/FORM and FLUT+FORM demonstrated similar improvements in lung function (pre-dose and 2-hour post dose $\mathrm{FEV}_{1}$ ) and symptom-based endpoints in the overall population, and in both subgroups.

Abstract P6 Table 1 Summary of LS mean changes from baseline for spirometric endpoints, overall and stratified by FEV1 \% predicted - ITT population

\begin{tabular}{|c|c|c|}
\hline Endpoint & $\begin{array}{l}\text { FLUT/FORM } \\
500 / 20 \mu \mathrm{g} \mathrm{n}=154\end{array}$ & $\begin{array}{l}\text { FLUT + FORM } 500 \mu \mathrm{g} \\
+24 \mu \mathrm{g} \mathrm{n}=156\end{array}$ \\
\hline \multicolumn{3}{|c|}{ Change in pre-dose FEV from Day 1 to Day 56} \\
\hline All patients & 0.346 & 0.267 \\
\hline Treatment difference $(95 \% \mathrm{Cl})$ & & $0.079(-0.032,0.190)$ \\
\hline$P$-value & & $P=0.164$ \\
\hline FEV1 $\leq 60 \%$ subgroup & 0.414 & 0.353 \\
\hline Treatment difference $(95 \% \mathrm{CI})$ & & $0.061(-0.108,0.231)$ \\
\hline$P$-value & & $P=0.477$ \\
\hline FEV1 $>60 \%$ subgroup & 0.260 & 0.173 \\
\hline Treatment difference $(95 \% \mathrm{CI})$ & & $0.087(-0.053,0.227)$ \\
\hline$P$-value & & $P=0.222$ \\
\hline \multicolumn{3}{|c|}{$\begin{array}{l}\text { Change in pre-dose } \mathrm{FEV}_{\text {, from pre-dose Day }} \\
1 \text { to } 2 \text {-hours post-dose Day } 56\end{array}$} \\
\hline All patients & 0.517 & 0.477 \\
\hline Treatment difference (95\% CI) & & $0.040(-0.069,0.149)$ \\
\hline$P$-value & & $P=0.471$ \\
\hline $\mathrm{FEV}_{1} \leq 60 \%$ subgroup & 0.569 & 0.577 \\
\hline Treatment difference $(95 \% \mathrm{CI})$ & & $0.007(-0.172,0.157)$ \\
\hline$P$-value & & $P=0.930$ \\
\hline $\mathrm{FEV}_{1}>60 \%$ subgroup & 0.449 & 0.367 \\
\hline Treatment difference $(95 \% \mathrm{CI})$ & & $0.082(-0.056,0.221)$ \\
\hline$P$-value & & $P=0.244$ \\
\hline
\end{tabular}

\section{P7 ASSESSING THE INTUITIVE EASE OF USE OF A NOVEL DRY POWDER INHALER, THE FORSPIRO ${ }^{\mathrm{T}}{ }^{\mathrm{D}}$ DEVICE, FOR ASTHMA AND COPD}

doi:10.1136/thoraxjnl-2012-202678.148

${ }^{1} \mathrm{~S}$ Jones, ${ }^{2} \mathrm{~T}$ Weuthen, ${ }^{3} \mathrm{O} \mathrm{J}$ Harmer, ${ }^{4} \mathrm{JC}$ Virchow. ${ }^{1}$ Sandoz GmbH, Holzkirchen, Germany, ${ }^{2}$ Aeropharm GmbH, Rudolstadt, Germany; ${ }^{3}$ Vectura Delivery Devices Ltd, Cambridge, UK; ${ }^{4}$ Universitatsklinik Rostock, Rostock, Germany

Poor inhaler technique has been recognised as a significant contributor to poor control.(1) A number of authors have attempted 